\title{
PARTISIPASI MASYARAKAT DALAM PELAKSANAAN PEMILIHAN UMUM
}

Oleh:

\author{
Anita Laki Mbatu \\ 2171B0004 \\ S-I Administrasi Rumah Sakit \\ IIK STRADA Inodesia \\ Anitambatu12@gmail.com
}

\begin{abstract}
Abstrak
Tulisan ini bertujuan untuk mengetahui peran peran partai politik dalam pelaksanaan pemilihan umum. Metode penulisan yang digunakan dalam tulisan ini metode penulisan kulitatif deskriftif dimana penelitian ini dituangkan dalam sebuah tulisan dalam bentuk uraian kalimat berdasarkan fakta dan data. Dari pembahasan dapat disimpulkan bahwa Negara yang demokratis memiliki keunggulan tersendiri karena dalam setiap pengambilan kebijakan mengacu pada aspirsi masyarakat. Masyarakat yang sebagai tokoh utama dalam sebuah Negara demokrasi memiliki peranan yang sangat penting. Salah satu peranan masyarakat dalam Negara demokrasi adalah partisipasi masyarakat dalam politik dalam hal ini pemilihan umum. Masyarakat memiliki peran yang sangat kuat dalam proses penentuan eksekutif dan legislatif baik dipemerintah pusat maupun daerah. Oleh karena itu perlu pendidikan politik yang harus diketahui oleh masyarakat agar pada saat pelaksaan pesta demokrasi tidak asal pilih dan hanya ikut-ikutan saja. Pendidikan politik yang baik akan menciptakan masyarakat yang cerdas sehingga mereka tidak akan salah pilih dalam memilih pemimpin atau wakil mereka. Dengan demikian keinginan dan harapan masyarakat dapat tersalurkan dan dapat dilaksanakan oleh pemerintah.
\end{abstract}

Kata kunci : patisipasi, masyarakat dan Pemilihan Umum

\section{A. Pendahuluan}

Proses pendewasaan demokrasi di Indonesia telah melalui masa 10 tahun sejak tahun 1999 dan dalam perjalanannya telah melewati berbagai proses yang penuh dengan dinamika kehidupan demokrasi. Pelaksanaan Pemilihan Umum untuk memilih anggota DPR-RI, DPRD Provinsi, \& DPRD Kab/Kota telah dilalui sebanyak 3 kali dengan 4 Presiden yang berbeda pasca pemerintahan Presiden Soeharto.
Dalam periode 10 tahu ke belakang telah banyak perubahan yang dialami Negara Kesatuan Republik Indonesia dalam menjalankan proses demokratisasi, diantaranya adalah Amandemen UUD 1945, kebebasan pers, pemisahan yang jelas antara militer dan sipil, kebebasan untuk mengeluarkan pendapat, dan lain-lain. Salah satu perubahan yang sangat penting sejak Reformasi adalah munculnya berbagai partai politik sebagai salah satu wujud kebebasan mengeluarkan pendapat, berserikat, 
dan berkumpul yang menjadi satu ciri utama Negara yang menjalankan sistem demokrasi.

Kebanyakan Negara demokrasi, pemilihan umum dianggap lambang sekaligus tolak ukur dari sebuah demokrasi. Hasil pemilu yang dilaksanakan dalam suasana keterbukaan dengan kebebasan berpendapat dan kebebasan berserikat dianggap mencerminkan sudah cukup mewakili partisipasi dan merupakan aspirasi masyarakat. Disadari bahwa pemilu bukan merupakan satu-satunya tolak ukur dan perlu dilengkapai dengan pengukuran kegiatan lainnya yang bersifat berkesinambungan.

Di negara dunia ketiga beberapa kebebasan seperti yang dikenal didunia barat kurang diindahkan. Dalam karangannya Budiardjo (2009:461) mengungkapkan dalam ilmu politik dikenal bermacam-macam sistem pemilihan umum dengan berbagai variasinya, akan tetapi pada umumnya berkisar pada dua prinsip pokok, yaitu:

a. Single-member constituency (satu daerah pemilihan memilih satu wakil; biasanya disebut sistem distrik).

b. Multi-member constituency (satu daerah pemilihan memilih beberap wakil; biasanya dinamakan sistem sistem perwakila berimabng atau sistem proporsional).

Pemilu merupakan sarana pengamalan demokrasi. Dapat dikatakan tidak ada demokrasi tanpa pemilu. Walaupun begitu, pemilu bukanlah tujuan, akan tetapi hanya sebagai sarana untuk memilih anggota parlemen dan pemimpin eksekutif di pusat dan daerah. Adapun tujuan kita berbangsa dan bernegara adalah antara lain untuk memajukan kesejahteraan umum dan mencerdaskan kehidupan bangsa sebagaimana tertuang dalam pembukaan UUD 1945.

Masyarakat memiliki peran yang sangat penting dalam penyelenggaraan pesta demokrasi seperti halnya pemilihan umum. Oleh karenanya masyarakat tidak dapat dipisahkan dengan pemilu karena merupakan satu kesatuan yang utuh dimana masyarakat menjadi faktor utama dan penentu berjalan suksesnya sebuah pelaksanaan pemilu. Pelaksanaan pemilu sangat berpengaruh terhadap proses perkembangan sebuah kebijakan pemerintah yang mengatur masyarakat banyak. Oleh karena itu sudah waktunya kita memberikan sebuah pembelajaran berharga kepada masyarakat mengenai makna dan arti dari sebuah pemilu itu sendiri sehingga masyarakat tidak terperosok kedalam sebuah kesalahan pada saat memilih kandidat pemilu.

Pembelajaran dan sosialisasi pemilu merupakan suatu hal yang sangat berpengaruh dan wajib dilakukan agar masyarakat benar-benar mengetahui tentang pemilu. Selain memberikan petunjuk teknis, masyarakat Indonesia masih perlu diberikan pengertian tentang bagaimana memberikan hak suaranya dengan benar dan bukan karena dipegaruhi hal lain yang tidak menguntungkan masyarakat itu sendiri. Pada dasarnya tujuan tersebut adalah memberikan petunjuk yang benar terkait pamilu bukan justru mencari keuntungan semata yang dapat merugikan masyarakat sehingga masyarakat hanya dijadikan boneka permainan politik oleh oknum yang tidak bertanggung jawab.

\section{B. PEMBAHASAN}




\section{Partisipasi Masyarakat dalam} Pelaksanaan Pemilu

Dalam analisis politik modern partisispasi politik meruapakan suatu maslaah yang penting dan akhir-akhir ini banyak dipelajari terutama hubungannya dengan Negara berkembang. Sebagai definisi umum dapat dikatakan bahwa partisipasi politik adalah kegiatan seseorang atau kelompok orang untuk ikut serta secara aktif dalam kehidupan politik, antara lain dengan jalan memilih pimpinan Negara secara langsung atau tidak langsung, memengaruhi kehidupan kebijakan (public policy).

Setiap perhelatan demokrasi atau pemiihan umum yang diselenggarakan oleh Negara Republik Indonesia memiliki dampak terhadap perkembangan kemajuan kehidupan berbangsa dan bernegara. Para elit politik sejatinya memberikan pendidikan politik yang cerdas kepada masyarakat agar kesadaran berdemokrasi semakin tinggi dari berbagai kalangan. Kesadaran berdemokrasi tersebut akan tinggi jika partisipasi masyarakat dalam memberikan haknya juga tinggi.

Karena itu, kesadaran masyarakat untuk berpartisipasi secara positif dalam sistem politik yang ada, jika seseorang tersebut merasa dirinya sesuai dengan suasana lingkungan dimana dia berada. Apabila kondisi yang terjadi adalah sebaliknya, maka akan lahir sikap dan tingkah laku politik yang tampak janggal atau negatif, misalnya jika seseorang sudah terbiasa berada dalam lingkungan berpolitik yang demokratis, tetapi dia ditempatkan dalam sebuah lingkungan masyarakat yang feodal atau tidak demokratis maka dia akan mengalami kesulitan dalam proses beradaptasi.

Meningkatnya keterlibatan masyarakat dalam penyelenggaraan Pemilihan Umum (Pemilu), menunjukan semakin kuatnya tatanan demokrasi dalam sebuah negara. Demokrasi menghendaki adanya keterlibatan rakyat dalam setiap penyelenggaraan yang dilakukan negara. Rakyat diposisikan sebagai aktor penting dalam tatanan demokrasi, karena pada hakekatnya demokrasi mendasarkan pada logika persamaan dan gagasan bahwa pemerintah memerlukan persetujuan dari yang diperintah. Keterlibatan masyarakat menjadi unsur dasar dalam demokrasi. Untuk itu, penyelenggaraan pemilu sebagai sarana dalam melaksanakan demokrasi, tentu saja tidak boleh dilepaskan dari adanya keterlibatan masyarakat.

Partisipasi politik akan berjalan selaras manakala proses politik berjalan secara stabill. Seringkali ada hambatan partisipasi politik ketika stabilitas politik belum bisa diwujudkan, karena itu penting untuk dilakukan oleh para pemegang kekuasaan untuk melakukan proses stabilisasi politik. Disamping itu pula proses berikutnya melakukan upaya pelembagaan politik sebagai bentuk dari upaya untuk memberikan kasempatan kepada masyarakat untuk mengaktualisasikan citacitanya.

Partisipasi politik tidak lebih dari keterlibatan individu sampai pada bermacammacam tingkatan, atau juga dijelaskan secara subtantif bisa berarti upaya atau usaha terorganisir oleh konstituen atau warga Negara yang baik untuk memilih para pemimpin yang mereka 
nilai baik juga. Partispasi ini mereka melakukannya dengan penuh tanggung jawab terhadap kehidupan bersama dalam lingkup suatu bangsa dan negara. Partisipasi politik ditekankan pada aspek untuk mendukung kepentingan-kepentingan atau visi dan misi elit politik tetentu.

Sebagai masyarakat yang bijak kita harus turut serta dalam proses prmilihan umum dalam rangka menentukan pemimpin yang akan memimpin kita. Dengan demikian, secara tidak langsung kita akan menentukan pembuat kebijakan yang akan berusaha mensejahterakan masyarakat secara umum. Dalam turut berpartisipasi dalam proses pemilihan umum sebagai masyarakat yang cerdas kita harus mampu menilai calon yang terbaik yang sekiranya mampu dan mau mendengarkan aspirasi masyarakat agar pembangunan yang akan dilakukan sesuai dengan keinginan masyarakat dan tidak memilih calon yang hanya mementingkan diri sendiri atau kelompoknya saja sehingga melupakan janji-janji yang sudah diucapkan dalam masa kampanye. Sebagai pemilik hak pemilih dalam pemilu kita jangan sampai menyia-nyiakan hak suara hanya untuk iming-iming sementara yang dalam artian kita harus memberikan suara kita kepada calon yang tepat. Ketidakikutsertaan kita sebenarnya justru akan membuat kita susah sendiri karena kita tidak turut memilih tetapi harus mengikuti pemimpin yang tidak kita pilih.

\section{Upaya Peningkatan Partisipasi Masyarakat dalam Pemilu}

Peningkatan partisipasi masyarakat sangat penting dalam pelaksanaan pemilihan umum dalam proses memilih anggota legislatif dan eksekutif. Karena bagaimanapun masyarakat memiliki andil yang cukup besar dalam proses pemilihan umum dimana masyarakat sebagai pemilih yang menentukan dalam pemenangan dalam proses pemilihan umum tersbut. Akan tetapi beberapa tahun terakhir partisipasi masyarakat akhir-akhir ini menurun karena disebabkan banyak faktor. Sudah menjadi tanggungjawab bersama bagaimana upaya untuk meningkatkan peran masyarakat dalam pemilu sebagai proses demokratisasi yang sudah berjalan di Indonesia.

Lembaga penyelenggara pemilu sudah berupaya meningkatkan partisipasi masyarakat dalam pemilihan umum agar masyarakat mau memberikan hak suaranya dalam proses pesta demokrasi tersebut. Komisi pemilihan umum sebagai lemabaga penyelenggara pemilihan umum di Indonesia sudah banyak strategi yang dilakukan untuk meningkatkan partisipasi masyarakat dalam pemilihan umum diantaranya memberikan pendidikan pemilih (vote education). Kegiatan ini tidak hanya dapat dilakukan oleh penyelenggara pemilu, namun bisa juga dilaksanakan oleh semua elemen bangsa ini, karena pemilu itu yang menentukan nasib bangsa, dalam menentukan wakil rakyat diparlemen dan pemimpin bangsa baik ditingkat pusat maupun di daerah. Kegiatan ini bertujuan untuk memberikan pengertian kepada masyarakat bagaimana tata cara dan peran masyarakat dalam pemilu dengan demikian masyarakat akan mengerti peran meraka dalam pesta demokrasi tersebut. 
Selain memberikan pendidikan dan sosialisasi kepada masyarakat, pendidikan pemilu juga bertujuan memberikan pemahaman kepada masyarakat mengenai demokrasi dan pentingnya partisipasi masyarakat dalam mensukseskan terselenggaranya pemilu dan pemilukada. Selain itu kegiatan tersebut juga bertujuan meningkatkan partisipasi masyarakat dalam pemilu yang berkualitas dan bertanggungjawab dalam kehidupan politik. Selain berupaya meningkatkan partisipasi masyarakat untuk ikut serta dalam proses pemilihan pemilu, komisi pemilihan umum juga berusaha menarik minat pemilih pemula untuk turut berpartisipasi dalam pemilihan umum. Partisipasi pemilih pemula sangat penting sebagai pembelajaran untuk berpartisipasi dalam dunia perpolitikan di Indonesia. Selain menarik minat, memberikan pemahaman dan pendidikan kepada pemilih pemula merupakan langkah yang sangat penting sehingga mereka tidak akan sembaranagn dalam menentukan pilihannya. Di Indonesia sendiri, pemilih dengan kisaran usia 17-21 tahun yang berstatus pelajar dan mahasiswa ini selalu menjadi topik, sehingga komisi pemilihan umum berupaya bagaimana caranya supaya mereka berpartisipasi secara aktif dalam Pemilu. Semua pihak setuju dan tidak mau kalau pemilih pemula tidak memiliki pendirian politik, atau suaranya malah mengambang dalam Pemilu.

Agar supaya sistem demokrasi semakin baik, dibutuhkan partisipasi semua pemilih, khususnya partisipasi pemilih pemula, hingga level partisipan bahkan level subjek. Pada kedua level ini, pemilih sudah sangat paham dan aktif terlibat pada semua tahapan pemilihan umum.

Strategi yang dilakukan lembaga penyelenggara pemilu dan pemerintah dalam menaraik minta pemilih pemula yang notabene masih muda maka strategi yang digunakanpun harus tidak jauh dari aktifitas positif anak muda. Misalnya saja lembaga pemilihan umum menyelenggarakan pertemuan pelajar dan mahasiswa dalam sebuah seminar terkait pendidikan pemilihan umum atau mengadakan pertemuan komunitas pemuda. Dengan melalu pendidikan politik kepada pemilih pemula maka diharapkan pemilih pemula benar-benar turut berpartisipasi dalam pemilihan umum bukan hanya sekedar datang ke TPS dan mencoblos karea sebagai pengalaman pertama bagi mereka.

\section{Pelaksanaan Pemilihan Umum}

Pemilu merupakan sarana pengamalan demokrasi. Dapat dikatakan tidak ada demokrasi, tanpa pemilu. Walaupun begitu, pemilu bukanlah tujuan. Ia hanya sebagai sarana untuk memilih anggota parlemen dan pemimpin eksekutif di pusat dan daerah. Adapun tujuan kita berbangsa dan bernegara adalah antara lain untuk memajukan kesejahteraan umum dan mencerdaskan kehidupan bangsa sebagaimana tertuangdalam pembukaan UUD 1945.

Secara teknis penyelenggaraan pemilihan umum dilakukan oleh komisi pemilihan umum sebaga lembaga penyelenggara pemilihan umum yang dibentuk pemerintah. Selain Jurnal Warta Edisi : 51 Januari 2017 | ISSN : 1829 7463 Universitas Dharmawangsa KPU, 
kesuksesan penyelenggaraan pemilahan umum juga harus mendapatkan dukungan dari masyarakat sebagai faktor penting dalam proses pemilihan.

Salah satu proses pelaksanaan pemilihan umum salah satunya adalah kampanye. Kampanye merupakan proses menarik simpatisan pemilu sebagai proses menarik perhatian simpatisan untuk mau memilih salah satu calon dalam pemilihan umum tersebut. Banyak cara yang dilakukan dalam masa kampanye untuk menarik simpatisan sebanyak mungkin. Pada umumnya tim sukses menggunakan hiburan rakyat sebagai daya tarik tersendiri agar semakin banyak simpatisan yang datang dengan harapan mereka mau memilih calon yang diunggulkan. Akan tetapi cara tersebut pada masa sekaran ini kurang begitu efektif karena tidak sedikit simpatisan yang datang hanya karena hiburannya bukan karena ingin memilih calon tersebut.

Budaya kampanye pada beberapa tahun terakhir mengalami pergeseran yang tadinya mengumpulkan masa di suatu tempat kini berubah dengan berkampanye dengan gaya "blusukan". Hal ini tidak terlepas dari kesuksesan Calon gubernur DKI Jakarta jokowi yang berhasil menarik perhatian masyarakat. Sebenarnya hal ini juga tidak terlepas dari ketokohan yang dimiliki calon sebagai daya tarik untuk menarik perhatian masyarakat sehingga masyarakat akan benar-benar memilih calon tersebut.

\section{Permasalahan dalam Pelaksanaan Pemilihan Umum}

Dalam setiap pelaksanaan kegiatan tidak menutup kemungkinan terjadi permasalahan dalam kegiatan tersebut meskipun presentasinya sangat kecil. Seperti halnya dalam pproses pelaksanaan pemilihan umum juga mengalami berbagai permasalahan yang dihadapi. Beberapa permasalahan dalam pelaksanaan pemilihan umum tersebut anatara lain:

a. Biaya yang mahal

Diakui bahwa pelaksanaan pemilihan umum di Indonesia masih sangat mahal hanya untuk menyelenggarakan pesta demokrasi tersebut. Hal ini dikarenakan proses pemilihan umum di Indonesia masih manual. Berbeda dengan Negara maju yang dalam proses pemiliohan umum sudah menggunakan teknologi canggih sehingga pelaksanaannya dapat lebih efisien dan efektif.

b. Golput

Golput atau golongan putih merupakan permasalahan yang sangat krusial karena merupakan permasalahan yang sangat sulit dipecahkan. Dari sudut pandang hak asasi manusia ini merupakan hal yang tidak dilarang oleh pemerintah Indonesia, berbeda dengan Negara negara maju, warga Negara yang tidak mau menggunakan hak pilihnya akan dikenakan sanksi misalnya di Negara Australia dan Cina.

\section{c. Penetapan daftar pemilih tetap}

Permasalahan ini biasanya terjadi pada pemilih pemula yang belum memiliki KTP atau pemilih yang baru pindah dari daerah satu kedaerah lain sehingga dama mereka tidak tercantum dalam DPT. Persoalan ini harus diselesaikan dengan cepat oleh 
pemerintah karena ini dapat emnghambat hak seseorang untuk dapat brepartisipasi dalam pemilu. Salah satu terobosan pemerintah untuk mengatasi persoalan ini adalah dengan membuat E-KTP Nasional Jurnal Warta Edisi : 51 Januari 2017 | ISSN : $1829 \quad$ - $7463 \quad$ Universitas Dharmawangsa yang dapat digunakan di setiap daerah. Dengan demikian hak seseorang untuk turut serta dalam pesta demokrasi tidak akan terhambat lagi.

\section{Pelanggaran dalam Pelaksanaan Pemilihan Umum}

Setiap pelaksanaan pemilihan umum pada umumnya pemilukada sudah bukan hal yang tabu bahwa pasti ada pelanggaran dalam pelaksanaan pemilihan umum tersebut yang tidak sedikit dapat menimbulkan konflik berkepanjangan yang pada akhirnya merugikan kedua belah pihak bahkan masyarakat juga terkena dampaknya. Misalnya saja yang baru saja terjadi diwilayah Kalimantan tengah, tepatnya dikabupaten Kotawaringin Barat terjadi konflik karena berawal dari sengketa pemilu yang dimana salah satu pasngan melakukan pelanggran pemilu. Terkait pelanggaran dalam pelaksanaan pemilu, maka penulis merangkum beberapa pelanggaran pemilu yang sering terjadi di beberapa daerah, antara lain:

\section{a. Kampanye hitam}

Kampanye hitam Yaitu kampanye yang bersifat menjelek-jelekkan calon lain, mengadu domba, memfitnah, menyebarkan berita bohong, menghasut, mengajak untuk tidak memilih calon lain, mengajak untuk tidak memilih calon yang tidak seiman. Hal demikian sangat dilarang karena dapat merugikan calon lain. Selain dapat merugikan calon lain, kampanye seperti ini sangat tidak mendidik masyarakat untuk menjadi lebih cerdas dalam bersikap bijak dalam pemilihan umum.

\section{b. Money politic (politik uang)}

Permasalahan pelanggran pemilu yang satu ini sudah seperti menjadi budaya karena terlalu banyak calon yang melakukan hal ini. politik uang juga merupakan tindakan yang tidak adil karena hanya akan menguntungkan bagi calon yang memiliki harta banyak. Selain itu hal ini tidak memberikan pendidikan yang baik terhadap masyarakat dan cenderung membodohi masyarakat. Masyarakat harus lebih bijak dalam menyikapi hal ini Karena kebijakan selama satu periode tidak cukup terbayar dengan "serangan fajar" yang hanya berisi Rp. 50.000,- saja.

\section{c. Kampanye yang tidak sesuai jadwal}

Meskipun KPU sudah merancang jadwal kampanye bagi setiap pasangan calon, tetapi masih ada saja pasangan calon yang curi start dalam pelaksanaan pemilu hal ini tentu sangat merugikan bagi pasangan lain. Selain itu hal tersebut rawan terjadi konflik karena banyaknya simpatisan yang berpotensi bentrok jadwal karena bertemu dijalan dan lain sebagainya. Selain kampanye tidak sesuai jadwal, banyak juga pasangan calon yang berkampanye di saran peribadatan dan saran pendidikan yang sudah jelas-jelas dilarang.

\section{d. Intimidasi}


Intimidasipada masa kampanye merupakan hal terlarang karena hal ini sagat bertentangan dengan hak asasi manusia. Pelanggran ini biasanya berbentuk ancaman, tindak kekerasan, salah satu pasangan calon. Selain itu tindak pelanggaran ini juga bisa merusak/menghilangkan alat peraga pasangan lain.

\section{e. Menggunakan fasilitas Negara}

Pelanggaran ini biasanya dilakukan oleh calon pasangan incumbent yang masih memiliki jabatan penting dalam pemerintahan. Hal paling sering dilakukan dengan Jurnal Warta Edisi : 51 Januari 2017 | ISSN : 1829 - 7463 Universitas Dharmawangsa menggunakan fasilitas Negara adalah intimidasi terhadap pegawai sampai dengan menggunakan anggaran Negara

\section{Partisipasi Partai Politik}

Peran partai politik telah memberikan kontribusi yang signifikan bagi sistem perpolitikan nasional, terutama dalam kehidupan masyarakat Indonesia yang dinamis dan sedang berubah. Jika kapasitas dan kinerja partai politik dapat ditingkatkan, maka hal ini akan berpengaruh besar terhadap peningkatan kualitas demokrasi dan kinerja sistem politik. Oleh karena itu, peran partai politik perlu ditingkatkan kapasitas, kualitas, dan kinerjanya agar dapat mewujudkan aspirasi dan kehendak rakyat dan meningkatkan kualitas demokrasi

Sistem politik Indonesia telah menempatkan Partai Politik sebagai pilar utama penyangga demokrasi. Artinya, tak ada demokrasi tanpa Partai Politik. Karena begitu pentingnya peran Partai Politik, maka sudah selayaknya jika diperlukan sebuah peraturan perundang-undangan mengenai Partai Politik. Peraturan perundang-undangan ini diharapkan mampu menjamin pertumbuhan Partai Politik yang baik, sehat, efektif dan fungsional. Dengan kondisi Partai Politik yang sehat, selektif dan fungsional, maka memungkinkan untuk melaksanakan rekrutmen pemimpin atau proses pengkaderan, pendidikan politik dan kontrol sosial yang sehat. Dengan Partai Politik pula, konflik dan konsensus dapat tercapai guna mendewasakan masyarakat. Konflik yang tercipta tidak lantas dijadikan alasan untuk memecah belah partai, tapi konflik yang timbul dicarikan konsensus guna menciptakan partai yang sehat dan fungsional.

Di satu sisi, banyaknya jumlah partai politik peserta pemilu dalam proses demokrasi di Indonesia merupakan suatu bentuk konsenkuensi logis dari penerapan sistem demokrasi secara konsisten, namun di sisi lain banyaknya jumlah partai politik tidak otomatis membuat kualitas pelaksanaan sistem demokrasi menjadi lebih baik, bahkan cenderung menjadi semakin buruk.

Mau atau tidak mau, suka atau tidak suka, semua partai politik akan berusaha untuk memperoleh dukungan sebesarbesarnya dalam suatu pemilihan umum untuk mempengaruhi arah kebijakan negara - Tinggal dengan cara apa partai politik akan menarik simpati rakyat untuk memperoleh dukungan rakyat pada periode pemilihan umum berikutnya di tahun 2014 , apakah akan tetap menggunakan pola-pola 
pendekatan lama atau akan menggunakan pola-pola pendekatan yang baru dengan konsekuensi akan menghadapi perjuangan yang sangat berat. Pandangan masyarakat terhadap partai politik yang dibuktikan dengan semakin berkurangnya partisipasi pemilih dalam pemilu 2009 bukan tanpa alasan, karena memang sampai hari ini belum nampak hasil kerja nyata partai poltik yang benar-benar berdampak positif bagi kehidupan masyarakat, khususnya setelah pelaksanaan Pemilihan Umum.

Menumbuhkan Partai Politik yang sehat dan fungsional memang bukan perkara mudah. Diperlukan sebuah landasan yang kuat untuk menciptakan Partai Politik yang benarbenar berfungsi sebagai alat artikulasi masyarakat. Bagi Indonesia, pertumbuhan Partai Politik telah mengalami pasang surut. Meski keberadaan Partai Politik saat ini dianggap kurang baik, Jurnal Warta Edisi : 51 Januari 2017 | ISSN : 1829 7463 Universitas Dharmawangsa bukan berarti dalam sistem ketatanegaraan kita menghilangkan peran dan eksistensi Partai Politik. Keadaan Partai Politik seperti sekarang ini hanyalah bagian dari proses demokrasi

\section{KESIMPULAN}

Dari uraian diatas maka dapat disimpulkan bahwa Negara yang demokratis memiliki keunggulan tersendiri karena dalam setiap pengambilan kebijakan mengacu pada aspirsi masyarakat. Masyarakat yang sebagai tokoh utama dalam sebuah Negara demokrasi memiliki peranan yang sangat penting. Salah satu peranan masyarakat dalam Negara demokrasi adalah partisipasi masyarakat dalam politik dalam hal ini pemilihan umum. Masyarakat memiliki peran yang sangat kuat dalam proses penentuan eksekutif dan legislatif baik dipemerintah pusat maupun daerah. Oleh karena itu perlu pendidikan politik yang harus diketahui oleh masyarakat agar pada saat pelaksaan pesta demokrasi tidak asal pilih dan hanya ikut-ikutan saja. Pendidikan politik yang baik akan menciptakan masyarakat yang cerdas sehingga mereka tidak akan salah pilih dalam memilih pemimpin atau wakil mereka. Dengan demikian keinginan dan harapan masyarakat dapat tersalurkan dan dapat dilaksanakan oleh pemerintah.

\section{DAFTAR PUSTAKA}

Budiardjo, Miriam.2009.Dasar-Dasar Ilmu Politik.Jakarta.PT. Gramedia Pustaka Utama. Detiknews.com_angka-golput-dimedan-dalam-pilgub-sumut-mencapai63,38-persen.htm (diakses 12/4/2013).

Hazim, Nur Kholit.2004.Kamus Lengkap bahasa Indonesia.Surabaya.Terbit Terang.

KPU kubu raya_seminar-peningkatanperan-serta-masyarakat-dalam-pemiludan- pemilukada.htm (diakses 12/4/2015).

Nawawi, Hadari.2007. Metode Penelitian Bidang Sosial.Yogyakarta.Gajah Mada University Press

Novia, Windy.2009.Kamus Ilmiah Populer.WIPRESS.

Okezonenews.com_ antisipasi-golputmendagri-usul-pilkada-digelar-hari-

kerja.htm (diakses 10 Maret 2015) Partisipasi Masyarakat dalam Politik 


\begin{tabular}{lrr} 
sebagai Implementasi & \multicolumn{2}{r}{ Nilai-nilai } \\
Demokrasi & di & \multicolumn{2}{c}{ Indoneisa } \\
febrisartika257.htm & (diakses & 10 \\
Maret 2015) & &
\end{tabular}

Sugiyono.2012.Metode Penelitian

Kuantitatif, Kualitatif, Dan

R\&D.Bandung.Alfabeta.-undang

Nomor 22 Tahun 2007 Tentang

Penyelenggara Pemilu. Undang-

undang Nomor 3 Tahun 1999 tentang

Pemilihan Umum. 